\title{
Fruit quality of pineapple 'Vitória' under macronutrients and boron deficiency
}

\author{
Jéssica Morais Cunha ${ }^{1}$, Marta Simone Mendonça Freitas², Luiz Carlos Santos Caetano ${ }^{3}$, \\ Almy Júnior Cordeiro de Carvalho ${ }^{4}$, Diego Alves Peçanha ${ }^{1}$, Paulo Cesar dos Santos ${ }^{5}$
}

Abstract - The objective of this study was to evaluate the influence of macronutrient and boron deficiencies on physico-chemical characteristics of pineapple fruits, 'Vitoria' cultivar. The experimental design was a randomized complete block with eight treatments (complete solution, $-\mathrm{N},-\mathrm{P},-\mathrm{K},-\mathrm{Ca},-\mathrm{Mg}$, $-\mathrm{S}$ and $-\mathrm{B}$ ) and six replicates. The experiment was conducted from October 2016 to March 2018, and the variables evaluated were: fresh fruit and crown mass, fruit diameter, fruit and crown length, juice volume and mass, titratable acidity (TA), soluble solids (SS), vitamin $\mathrm{C}$, juice $\mathrm{pH}$ and SS/TA ratio. All treatments with nutrient deficiency reduced the fresh fruit mass. In treatments $-\mathrm{N}$ and $-\mathrm{Ca}$ there was a reduction of 41.9 and $35.3 \%$, respectively, in the crown fresh mass. Fruits diameter under N, K and Mg deficiency was lower, fruit length, soluble solids and juice $\mathrm{pH}$ were lower in treatment with $\mathrm{N}$ deficiency. Isolated deficiencies of each of the macronutrients and $\mathrm{B}$ reduced the mass of the whole fruit and the crownless fruit. The nutrient that most limited the size and quality of 'Vitoria' pineapple fruit was nitrogen.

Index terms: Ananas comosus var. comosus, mineral nutrition, fruit growing, total soluble solids, titratable acidity.

\section{Qualidade de frutos de abacaxizeiro 'Vitória' sob deficiência de macronutrientes e boro}

Corresponding author: jessimcunha@yahoo.com.br

Received: May 01, 2019 Accepted: August 16, 2019

Copyright: All the contents of this journal, except where otherwise noted, is licensed under a Creative Commons Attribution License.

(cc) $\mathbf{E Y}$

\begin{abstract}
Resumo - Objetivou-se avaliar a influência das deficiências de macronutrientes e de boro nas características físico-química dos frutos de abacaxizeiro da cultivar Vitória. O delineamento experimental foi em blocos ao acaso, com oito tratamentos (solução completa, $-\mathrm{N},-\mathrm{P},-\mathrm{K},-\mathrm{Ca},-\mathrm{Mg}$, -S e -B) e seis repetições. A condução do experimento foi de outubro de 2016 a março de 2018, e as variáveis avaliadas foram: massas frescas do fruto e da coroa, diâmetro do fruto, comprimentos do fruto e da coroa, volume e massa do suco, acidez titulável (AT), sólidos solúveis (SS), vitamina $\mathrm{C}, \mathrm{pH}$ do suco e relação SS/AT. Todos os tratamentos com deficiência de nutrientes reduziram a massa fresca do fruto. Nos tratamentos $-\mathrm{N}$ e -Ca, houve redução de 41,9 e 35,3\%, respectivamente, na massa fresca da coroa. O diâmetro dos frutos, sob deficiência de $\mathrm{N}, \mathrm{K}$ e $\mathrm{Mg}$, foi menor, já o comprimento do fruto, os sólidos solúveis e o $\mathrm{pH}$ do suco foram menores no tratamento deficiente em N. Deficiências isoladas de cada um dos macronutrientes e de B reduziram a massa fresca do fruto inteiro e do fruto sem coroa. O nutriente que mais limitou o tamanho e a qualidade do fruto de abacaxizeiro 'Vitória' foi o nitrogênio.
\end{abstract}

Termos para indexação: Ananas comosus var. comosus, nutrição mineral, fruticultura, sólidos solúveis, acidez titulável.

\footnotetext{
${ }^{1}$ Doctorate student in Plant Production., Universidade Estadual do Norte Fluminense Darcy Ribeiro, Campos dos Goytacazes-RJ, Brasil. E-mails: jessimcunha@yahoo.com.br ${ }^{\text {(ORCID 0000-0002-8092-4726) }}$; diegopecanha333@yahoo.com.br (ORCID 0000-0002-5480-0121)

${ }^{2}$ Dr. in Plant Production. Professor of Plant Mineral Nutrition, Universidade Estadual do Norte Fluminense Darcy Ribeiro, Campos dos Goytacazes-RJ, Brasil. E-mail: martasimonefreitas@hotmail.com (ORCID 0000-0002-5104-3129)

${ }^{3}$ Dr. in Plant Production. Researcher of Instituto Capixaba de Pesquisa, Assistência Técnica e Extensão Rural-ES, Brasil. E-mail: luizcaetano1966@gmail.com ${ }^{\text {(ORCID 0000-0003-0907-5028) }}$

${ }^{4}$ Dr. in Plant Production. Professor of fruitculture, Universidade Estadual do Norte Fluminense Darcy Ribeiro, Campos dos Goytacazes-RJ, Brasil. E-mail: almy@fruticultura.org (ORCID 0000-0002-5895-4005)

${ }^{5}$ Dr. in Plant Production. Universidade Estadual do Norte Fluminense Darcy Ribeiro, Campos dos Goytacazes-RJ, Brasil. E-mail: pcsantos18@ hotmail.com ${ }^{\text {(ORCID } 0000-0002-8759-1653)}$
} 


\section{Introduction}

Pineapple is one of the most traditional and consumed fruits in the world, and is considered the third most produced tropical fruit, behind only banana and citrus. In Brazil, pineapple is the sixth fruit in harvested area, especially in the north, northeast and southeast regions (IBGE, 2017; REINHARDT et al., 2018; FAOSTAT, 2018).

Among the problems that limit pineapple production in Brazil, fusariosis has been the most serious disease caused by Fusarium guttiforme fungus, because it causes yield losses that can reach $40 \%$ of marketable fruits and $20 \%$ of planting material. The best way to eliminate these losses is to grow resistant varieties, a more economical, efficient and environmentally safe alternative. Launched in 2006, 'Vitória' cv. presents resistance to fusariosis, absence of thorns in the leaves and fruit crown and fruits of cylindrical shape and white flesh (VENTURA et al., 2009).

Fruit quality is determined by its aroma and taste, which result from a combination of different metabolites, sugars, organic acids, volatile compounds and proteins (FORNEY, 2001). According to Ogawa et al. (2017), pineapple has high energy content and nutritional value due to its high concentration of carbohydrates, minerals (calcium, potassium, phosphorus, magnesium, sodium, copper and iodine) and vitamins, especially ascorbic acid, niacin, thiamine and riboflavin.

Pineapple fruits, considered to be of better quality, have high sugar content and moderate titratable acidity, and the last factor is inversely correlated with the $\mathrm{pH}$ and vitamin C of the fruit juice (RAMOS et al., 2010). The ratio of soluble solids and titratable acidity increases with advancing in fruit ripening. This ratio is one of the most widely used ways of assessing taste, being more representative than the isolated measurement of sugars or acidity, showing the balance between these two components (BERILLI et al., 2011; OGAWA et al., 2017). According to the Horticulture Quality Center - HQC (2003), the soluble solids content in pineapple fruits, among other quality requirements, must be above $12^{\circ} \mathrm{Brix}$, considered minimum for commercialization in Brazil.

To ensure good fruits acceptance in the consumer market, producers seek to raise quality standards by optimizing their mineral fertilizer system (AMORIM et al., 2011). The increase in pineapple fruit mass can be obtained when plants are subjected to adequate mineral fertilization (COELHO et al., 2007). The nutritional status of pineapple has a great influence on its development, especially in the pre-flowering phase that directly influences fruit production and quality (BHOWMICK et al., 2017; CAETANO et al., 2013; GUARÇONI and VENTURA, 2011).

Some studies on mineral nutrition and fruit quality with pineapple cultivars such as 'Vitória' (CAETANO et al., 2013) 'Gold (MD-2)' (GUARÇONI and VENTURA, 2011), 'Jupi' (COELHO et al., 2007), 'Pérola' (VELOSO et al., 2001) and 'Imperial' (RAMOS et al., 2010; OLIVEIRA et al., 2015; RIOS et al., 2018) demonstrate the influence of nitrogen and potassium on soluble solids and titratable acidity, juice yield and vitamin $\mathrm{C}$ content, with each cultivar presenting its peculiarities. In general, nitrogen has a negative effect on soluble solids and titratable acidity, while potassium has a positive effect on these characteristics.

Thus, the study of plant responses to nutrient supply is an important tool for proper crop management (AULAR and NATALE, 2013). It is found that information about 'Vitória' pineapple fruits when grown under macronutrient and boron nutritional deficiency is still unknown, notably with regard to fruit quality; and values of 'Pérola' and 'Smooth Cayenne' cultivars were erroneously used as a comparative parameter, although they have similarities.

In this context, the objective of this study was to evaluate the effect of nitrogen, phosphorus, potassium, calcium, magnesium, sulfur and boron deficiencies on the physicochemical quality and development of pineapple fruits of 'Vitória' cultivar.

\section{Material and methods}

The experiment was conducted in a greenhouse of the Research Support Unit of the Universidade Estadual do Norte Fluminense Darcy Ribeiro, in Campos dos Goytacazes-RJ. Maximum and minimum temperatures and relative humidity within the greenhouse were recorded throughout the experimental period (Figure 1). The experimental design was randomized blocks with six replications and eight treatments represented by the following nutrient solutions: complete solution (CS) and solutions deficient in nitrogen $(-\mathrm{N})$, phosphorus $(-\mathrm{P})$, potassium $(-\mathrm{K})$, calcium $(-\mathrm{Ca})$, magnesium $(-\mathrm{Mg})$, sulfur (-S) and boron (-B). Each experimental unit was represented by a plant individually grown.

We used shoot type seedlings of pineapple of 'Vitória' cv. obtained at the Cachoeiro de Itapemirim experimental station of the Capixaba Institute for Research, Technical Assistance and Rural Extension. The seedlings were selected by weight, with an average mass of 340 grams, and planted in pots of 20 L capacity, filled with washed sand, in October 2016.

In January 2017 started the application of the complete solution in all plants (Table 1), based on the solution proposed by Hoagland and Arnon (1950). The conductivity of the nutrient solution was maintained between 2.0 and $2.2 \mathrm{mS}$ and the $\mathrm{pH}$ between 5.5 and 5.9 using $\mathrm{NaOH}$ solution $\left(2 \mathrm{~mol} \mathrm{~L}^{-1}\right)$ and $\mathrm{HCl}\left(0.1 \mathrm{~mol} \mathrm{~L}^{-1}\right)$ for the necessary corrections. The nutrients' concentration used in the complete solution in $\mathrm{mg} \mathrm{L}^{-1}$ was: $\mathrm{N}, 224 ; \mathrm{P}, 31$; 
K, 234; Ca, $160 ; \mathrm{Mg}, 48.6 ; \mathrm{S}, 80 ; 0 ; \mathrm{Cl}, 1.77$; Mn, 0.55; $\mathrm{Zn}, 0.13 ; \mathrm{Cu}, 0.03 ; \mathrm{Mo}, 0.06 ; \mathrm{B}, 0.27$; and Fe-EDTA, 2.23.

In April 2017, the applications of the treatments with deficiencies began (Table 1). The volume of the applied solution per plant in each treatment increased throughout the development of the plants, starting from $200 \mathrm{~mL}$ per day and finishing in one liter three times a week, on warmer days, in addition to the solution with treatments, deionized water was provided.

In July 2017, when the 'D' leaf of the complete solution treatment reached, on average, $66 \mathrm{~cm}$ in length and $27 \mathrm{~g}$ of fresh mass, floral induction of the plants was performed using Ethre ${ }^{\circledR}$ (Etefon) aqueous syrup at $0.1 \%$ with addition of urea at $2 \%$, in the volume of $30 \mathrm{~mL}$ per plant. On that date, ' $\mathrm{D}$ ' leaves were also collected for the determination of nutritional contents of each element in the complete solution and the respective deficient treatments, using the whole ' $\mathrm{D}$ ' leaf according to the methodology by Siebeneichler et al. (2002).

Thirteen months after planting, in November 2017 fruits began to be harvested when they reached stage five of maturation (OGAWA et al., 2017). The harvest took place during 70 days, according to the natural maturation of the fruits (Figure 2). The fruits were harvested and assigned for analysis afterwards.

The biometric characteristics evaluated in the fruits were: whole fruit mass, crownless fruit mass, crown mass, fruit length, crown length and fruit diameter. To obtain mass data, a digital scale was used. For the length data, a tape measure was used.

In the juice extracted from each fruit by cold pressing, the following variables were determined: titratable acidity (TA), soluble solid content (SS), $\mathrm{pH}$, vitamin $\mathrm{C}$ content and calculated $\mathrm{SS} / \mathrm{TA}$ ratio. Titratable acidity was obtained by titration with $0.1 \mathrm{~N}$ sodium hydroxide, expressed as \% of citric acid (g $100 \mathrm{~mL}^{-1}$ of juice); soluble solids ( ${ }^{\circ}$ Brix) were determined by refractometry using a digital refractometer; the juice $\mathrm{pH}$ was determined by digital $\mathrm{pH}$ meter. Vitamin $\mathrm{C}$ (ascorbic acid $100 \mathrm{~mL}^{-1}$ of juice) was dosed by titrating the juice with 2.6-dichlorophenol-indophenol sodium salt solution (AOAC, 2016).

Data were subjected to analysis of variance; and for the characteristics of the fruits, the means compared with the control (complete treatment) by the Dunnett bilateral test; while for the leaf contents characteristics, the Tukey test was used, both at $5 \%$ probability using the Statistical Analysis System (SANEST).

\section{Results and discussion}

We verified that at the moment of the floral induction, performed at 73 days after the beginning of the treatments application, the deficiencies of macronutrients and boron determined significant changes in nutritional content of pineapple leaves of 'Vitoria' cultivar (Table 2 ), and on the fruits quality harvested at 255 days after the beginning of the treatments (Table 3 ). This occurred even though the plants showed no visual symptoms of deficiency, except those grown without $\mathrm{N}$, which presented generalized yellowing and lower vegetative growth. In the treatment without $\mathrm{N}$, the content of this nutrient was $41.1 \%$ lower compared to its nutritional content with complete solution (Table 2).

The fresh mass of whole fruits and crownless fruits in the treatments with macronutrient and boron deficiencies were smaller, when compared with the fruits of the complete solution treatment (Table 3 ). All deficiency nutrient in the nutritious solution reduced the average fruit mass, especially the $\mathrm{N}$, which reduced the mass by $43.3 \%$ compared to the complete solution treatment. Fruit length and diameter also decreased, but in smaller proportions than fruit mass (Figure 2). Results of many researches, such as Guarçoni and Ventura (2011), Caetano et al. (2013) and Silva et al. (2012), confirm that $\mathrm{N}$ is the nutrient that has the greatest effect on pineapple productivity.

However, the fruits fresh mass harvested in the present study in the complete solution treatment were higher than those obtained in studies by Ventura et al. (2009), Caetano et al. (2013) and Silva et al. (2012) which worked under field cultivation and conventional management conditions for the 'Vitoria' pineapple.

The fresh crown mass in the treatments under $\mathrm{N}$ and $\mathrm{Ca}$ nutritional deficiency were 41.9 and $35.3 \%$, respectively, lower as compared to fresh crown mass of fruits from the complete solution treatment (Table 3). Ramos et al. (2009), working with treatments with nutritional deficiency in pineapple of 'Imperial' cv. also observed reductions in fresh fruit crown mass in response to $\mathrm{N}$ and $\mathrm{Ca}$ deficiency.

The crown studies of pineapple fruits are carried out in order to establish the optimal crown / fruit ratio. This ratio is relevant as to the esthetics of the fruit, as well as contribute to the handling during the fruit harvesting and transportation. In all treatments, the crown / fruit ratio did not exceed $18 \%$ of the fruit mass, being within the esthetic standards for fresh marketing. Preferably, the market is demanding for fruits that have small crowns in order to provide better appearance when offered to consumers (BENGOZI et al., 2007).

Fruits from plants cultivated under treatments deficient in $\mathrm{N}, \mathrm{K}$ and $\mathrm{Mg}$ presented diameter, $17.6 \%$, $12.6 \%$ and $11.8 \%$, respectively, lower compared to the complete solution treatment, while the other treatments 
did not differ significantly from the complete solution pattern. Caetano et al. (2013) demonstrated that variables such as fruit diameter and fruit length have a high positive correlation with fruit mass.

Plants grown in treatments deficient in $\mathrm{N}, \mathrm{K}, \mathrm{Mg}, \mathrm{S}$ and $B$ produced fruits with lower juice volumes compared to the complete treatment (Table 3). Juice mass reduced $46.0 \%$ only in N-deficient treatment.

Soluble solids content is a widely used medium for evaluating the quality of fruit extracts (MACHADO FILHO et al., 2018). The soluble solids content in the complete solution treatment was $14.3^{\circ}$ Brix, lower than that observed by Ventura et al. (2009) who reported a value of $15.8^{\circ} \mathrm{Brix}$ for the same cultivar (Table 3 ). These values are higher than those found in the fruits of 'Perola' and 'Smooth Cayenne' cultivars in studies by Reinhardt and Medina (1992) and similar to those found by Viana et al. (2013) and Küster et al. (2018) with the 'Vitoria' cultivar. On the other hand, Barker et al. (2018) and Berilli et al. (2014) reported higher average values of $16^{\circ}$ Brix for 'Vitoria' cultivar. The soluble solids content observed in fruits from plants grown with complete solution is within the minimum parameter for commercialization of pineapple fruits, which are the soluble solids content of $12^{\circ}$ Brix (BRASIL, 2002). For industry, the higher the value of the fruits' soluble solids, the smaller the amount of fruits used for juice concentration (NEGREIROS et al., 2008).

In $\mathrm{N}$-deficient treatment the soluble solids content was much higher $\left(19.1^{\circ} \mathrm{Brix}\right)$ compared to the complete treatment (14.3 ${ }^{\circ}$ Brix). $\mathrm{N}$ deficiency determined lower fruit growth, resulting in higher concentration of soluble solids, an opposite effect to that observed by Teixeira et al. (2002).

The juice $\mathrm{pH}$ was significantly affected only by the treatment with nitrogen deficiency, reducing it from 3.78 to 3.27 (Table 3). The value found in this study is higher than the values cited for the same cultivar by Silva (2012), which ranged from 3.67 to 3.90 , by Berilli (2014) of 3.6 and by Silva et al. (2015) of 3.44.

Juice acidity was lower in the treatment with potassium deficiency, with $0.44 \%$ of citric acid compared to the complete treatment with $0.69 \%$ of citric acid, which should be related to the effect of potassium ions on osmotic regulation and in the enzymatic activation within the cell. Monovalent cations, such as potassium ion, can form electrostatic bonds with the carboxylic groups of many organic acids, including citric acid (TAIZ et al., 2017). And the disorders caused by potassium deficiency affect the composition and formation of these compounds, damaging the fruits nutritional quality.

Potassium deficiency decreased titratable acidity and increased the SS/TA ratio significantly (Table 3 ). Spironello et al. (2004), studying the influence of NPK doses on fruit yield and quality of 'Smooth Cayenne' cultivar, observed the positive effect of potassium fertilization on soluble solids content, fruit acidity and vitamin $\mathrm{C}$ content, giving a balanced ratio between sugars/acids. Oliveira et al. (2015) studying nitrogen and potassium fertilization in 'Imperial' cultivar, observed linear increase in soluble solids and titratable acidity with increasing doses of $\mathrm{K}_{2} \mathrm{O}$ applied to the soil, while the sugars/acids ratio decreased linearly.

It was observed in fruits of treatments deficient in nitrogen and sulfur an increase in titratable acidity when compared to the averages observed in the complete solution treatment (Table 3). Similar results were observed by Ramos et al. (2010) on fruits of 'Imperial' cultivar, very high values, greater than $1 \%$. Nitrogen and sulfur deficiencies reduce amino acid and protein synthesis, promoting greater availability of organic acids such as malic acid, tricarboxylic acids and ascorbic acid, the last helping the stress defense in plants (TAIZ et al., 2017).

Ascorbic acid content is used as quality index for pineapple fruits, varying according to management conditions (LEE and KADER, 2000; RIOS et al., 2018). Ascorbic acid content in fruits of the complete treatment was $80.8 \mathrm{mg} \mathrm{L}^{-1}$ (Table 3) below that reported by Ramos et al. (2010) who observed levels above $100 \mathrm{mg} \mathrm{L}^{-1}$ of vitamin $\mathrm{C}$. In the treatment with nitrogen deficiency, vitamin $\mathrm{C}$ content had an increase of $46.8 \%$ over the complete treatment solution. According to Lee and Kader (2000), in low concentrations of $\mathrm{N}$, the accumulation of ascorbic acid occurs due to the lower biosynthesis of proteins and photoassimilates that are directed to the synthesis of secondary metabolism compounds. In the treatment with boron deficiency there was a decrease of $23.6 \%$ in vitamin $C$ content. According to Taiz et al. (2017) boron deficiency affects the synthesis of nucleic acids, compromising the ascorbic acid/vitamin $\mathrm{C}$ content in fruits.

The SS/TA ratio is an important factor for consumer acceptance as it directly influences fruit flavor (OGAWA et al., 2017). This ratio is also used to evaluate fruit maturity and palatability stage (SALOMÃO et al., 1988; OGAWA et al., 2017). The higher the value of this ratio indicates that fruits tend to have lower titratable acidity and higher soluble solids content. Only the treatment with potassium deficiency had a lower titratable acidity value than the complete treatment, and a $45.0 \%$ increase in the value of this ratio was observed in this treatment. Caetano et al. (2015), evaluating yield potential, plant characteristics and fruit quality of new fusarium-resistant pineapple hybrids, observed higher values of this ratio, 25.1, for the same cultivar under field cultivation conditions. 
Table 1. Composition of stock solutions used in treatment formulation: Complete solution and solutions deficient in nitrogen (-N), phosphorus (-P), potassium (-K), calcium (-Ca), magnesium (-Mg), sulfur (-S) and boron (-B), all based on Hoagland and Arnon Solution (1950).

\section{Treatment}

\begin{tabular}{ccccccccc}
\hline Stock solutions & Complete & $-\mathbf{N}$ & $-\mathbf{P}$ & $-\mathbf{K}$ & $-\mathbf{C a}$ & $-\mathbf{M g}$ & $\mathbf{- S}$ & $\mathbf{- B}$ \\
$\mathrm{Ca}\left(\mathrm{NO}_{3}\right)_{2} 4 \mathrm{H}_{2} \mathrm{O}\left(2 \mathrm{~mol} \mathrm{~L}^{-1}\right)$ & 2.0 & - & 2.0 & 2.0 & - & 2.0 & 2.0 & 2.0 \\
$\mathrm{KNO}_{3}\left(2 \mathrm{~mol} \mathrm{~L}^{-1}\right)$ & 3.0 & - & 3.0 & - & 3.0 & 3.0 & 3.0 & 3.0 \\
$\mathrm{NH}_{4} \mathrm{H}_{2} \mathrm{PO}_{4}\left(1 \mathrm{~mol} \mathrm{~L}^{-1}\right)$ & 1.0 & - & - & 1.0 & 1.0 & 1.0 & 1.0 & 1.0 \\
$\mathrm{MgSO}_{4}\left(1 \mathrm{~mol} \mathrm{~L}^{-1}\right)$ & 2.0 & 2.0 & 2.0 & 2.0 & 2.0 & - & - & 2.0 \\
$\mathrm{FeEDTA}\left(25 \mathrm{~g} \mathrm{~L}^{-1}\right)$ & 1.0 & 1.0 & 1.0 & 1.0 & 1.0 & 1.0 & 1.0 & 1.0 \\
$\mathrm{MICRO}^{*}$ & 1.0 & 1.0 & 1.0 & 1.0 & 1.0 & 1.0 & 1.0 & 1.0 \\
$\mathrm{H}_{3} \mathrm{BO}_{3}\left(25 \mathrm{mM}^{2}\right)$ & 1.0 & 1.0 & 1.0 & 1.0 & 1.0 & 1.0 & 1.0 & - \\
$\left(\mathrm{NH}_{4}\right)_{2} \mathrm{SO}_{4}\left(1 \mathrm{~mol} \mathrm{~L}^{-1}\right)$ & 0.5 & - & 1.0 & 0.5 & 0.5 & 0.5 & - & 0.5 \\
$\mathrm{NH}_{4} \mathrm{Cl}_{\left(1 \mathrm{~mol} \mathrm{~L}^{-1}\right)}$ & - & - & 1.0 & - & - & - & 1.0 & - \\
$\mathrm{NaNO}_{3}\left(2 \mathrm{~mol} \mathrm{~L}^{-1}\right)$ & - & - & - & 3.0 & 4.0 & - & - & - \\
$\mathrm{Na}_{2} \mathrm{SO}_{4}\left(1 \mathrm{~mol} \mathrm{~L}^{-1}\right)$ & - & - & - & - & - & 2.0 & - & - \\
$\mathrm{MgCl}_{2}\left(1 \mathrm{~mol} \mathrm{~L}^{-1}\right)$ & - & - & - & - & - & - & 2.0 & - \\
$\mathrm{CaCl}_{2}\left(2 \mathrm{~mol} \mathrm{~L}^{-1}\right)$ & - & 2.0 & - & - & - & - & - & - \\
$\left.\mathrm{KCl}_{(1 \mathrm{~mol} \mathrm{~L}}^{-1}\right)$ & - & 4.0 & - & - & - & - & - & - \\
$\mathrm{KH}_{2} \mathrm{PO}_{4}\left(1 \mathrm{~mol} \mathrm{~L}^{-1}\right)$ & - & 1.0 & - & - & - & - & - & - \\
$\mathrm{K}_{2} \mathrm{SO}_{4}\left(0.5 \mathrm{~mol} \mathrm{~L}^{-1}\right)$ & - & 1.0 & - & - & - & - & - & - \\
\hline
\end{tabular}

*Micro: $\mathrm{CuSO}_{4} 5 \mathrm{H}_{2} \mathrm{O}=250 \mathrm{mg} \mathrm{L}^{-1}, \mathrm{KCl}=3728 \mathrm{mg} \mathrm{L}^{-1}, \mathrm{MnSO}_{4} \mathrm{H}_{2} \mathrm{O}=845 \mathrm{mg} \mathrm{L}^{-1}, \mathrm{ZnSO}_{4} \cdot 7 \mathrm{H}_{2} \mathrm{O}=578 \mathrm{mg} \mathrm{L}^{-1},\left(\mathrm{NH}_{4}\right) 6 \mathrm{Mo}_{7} \mathrm{O}_{24} \cdot 4 \mathrm{H}_{2} \mathrm{O}=88 \mathrm{mg} \mathrm{L}^{-1}$

Table 2. Nutritional contents of 'Vitória' pineapple ' $\mathrm{D}$ ' leaf in response to treatments with complete nutrient solution $(\mathrm{CS})$ and with deficient solutions in nitrogen $(\mathrm{N})$, phosphorus $(\mathrm{P})$, potassium $(\mathrm{K})$, calcium $(\mathrm{Ca})$, magnesium $(\mathrm{Mg})$, sulfur (S), boron (B) at the time of flower induction at 270 days after planting and 73 days after the beginning of the treatments. Campos dos Goytacazes, 2019.

\begin{tabular}{cccccccc}
\hline \multirow{2}{*}{ Treatment } & $\mathbf{N}$ & $\mathbf{P}$ & $\mathbf{K}$ & $\mathbf{C a}$ & $\mathbf{M g}$ & $\mathbf{S}$ & $\begin{array}{c}\text { B } \\
\mathrm{mg} \mathrm{kg}^{-1}\end{array}$ \\
\hline CS & $12.5 \mathrm{a}$ & $1.50 \mathrm{a}$ & $29.8 \mathrm{a}$ & $2.83 \mathrm{a}$ & $2.61 \mathrm{a}$ & $1.11 \mathrm{a}$ & $14.1 \mathrm{a}$ \\
Deficiency & $7.15 \mathrm{~b}$ & $1.18 \mathrm{~b}$ & $19.9 \mathrm{~b}$ & $2.30 \mathrm{~b}$ & $1.44 \mathrm{~b}$ & $0.80 \mathrm{~b}$ & $8.08 \mathrm{~b}$ \\
\hline CV $(\%)$ & 16.2 & 16.4 & 14.5 & 11.9 & 16.1 & 20 & 10.6 \\
\hline
\end{tabular}

Means followed by the same letter in the column do not differ from each other by Tukey's test at $5 \%$ significance. 


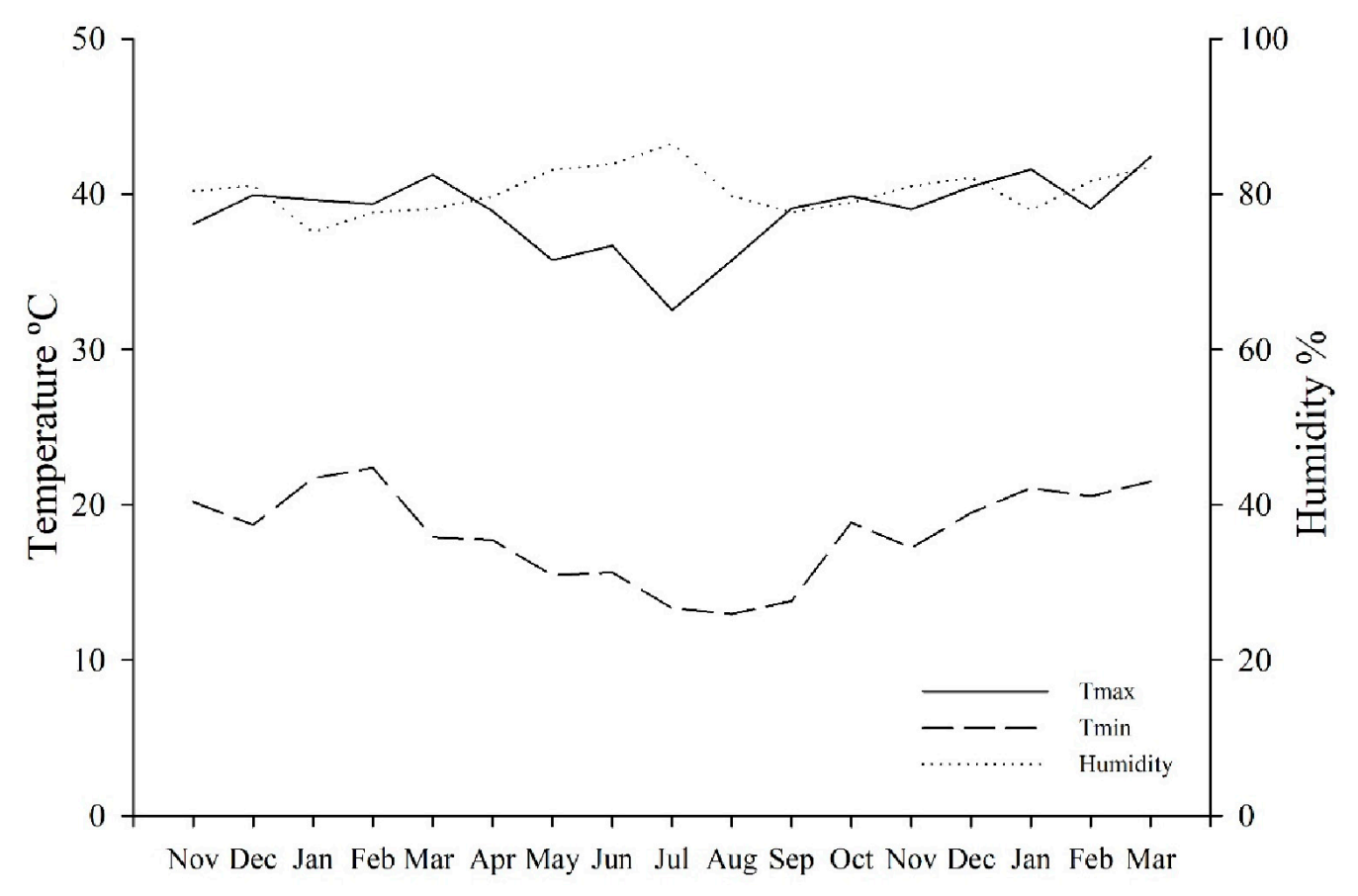

Figure 1. Average daily values of temperature $\left({ }^{\circ} \mathrm{C}\right)$ and relative humidity $\mathrm{RH}(\%)$ in greenhouse during the cultivation of pineapple plant of 'Victoria' cv., from November 2016 to March 2018. Campos dos Goytacazes, 2019.

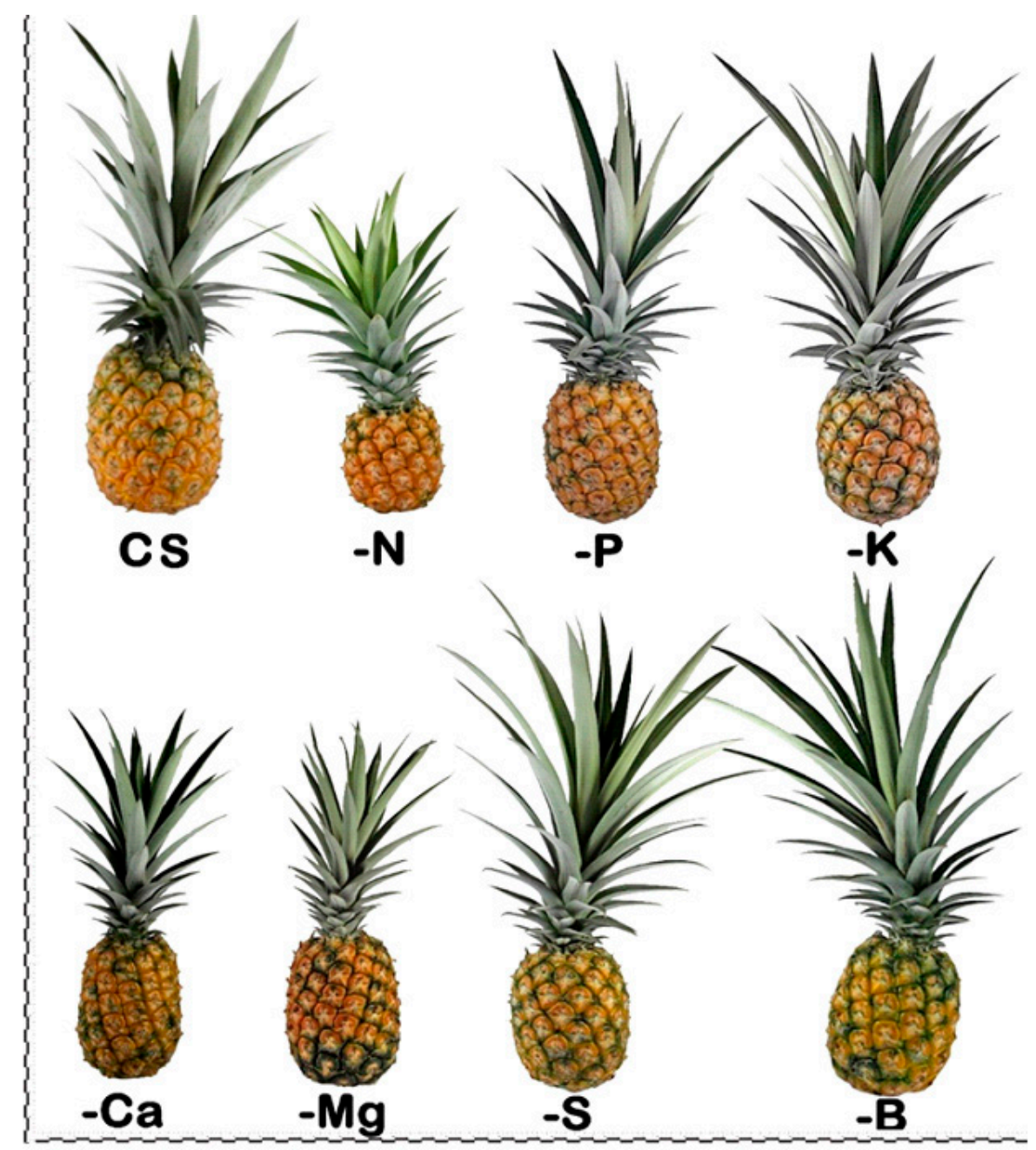

Figure 2. 'Vitória' pineapple fruits depending on the treatments: Complete Solution (CS) and deficiencies in nitrogen $(\mathrm{N})$, phosphorus $(\mathrm{P})$, potassium $(\mathrm{K})$, calcium $(\mathrm{Ca})$, magnesium $(\mathrm{Mg})$, sulfur $(\mathrm{S})$ and boron $(\mathrm{B})$. The image scale represents 1: $1 \mathrm{~cm}$. Campos dos Goytacazes, 2019. 
Table 3. Masses of the whole fruit, crownless fruit and crown, fruit length and diameter, crown length, juice volume and mass, $\mathrm{pH}$, soluble solids (SS), titratable acidity (TA), SS/TA ratio and juice vitamin C in pineapple fruits of 'Vitoria' cv. grown in complete solution $(\mathrm{CS})$ and deficiencies in nitrogen $(\mathrm{N})$, phosphorus $(\mathrm{P})$, potassium $(\mathrm{K})$, calcium $(\mathrm{Ca})$, magnesium (Mg), sulfur (S) and boron (B). Campos dos Goytacazes, 2019.

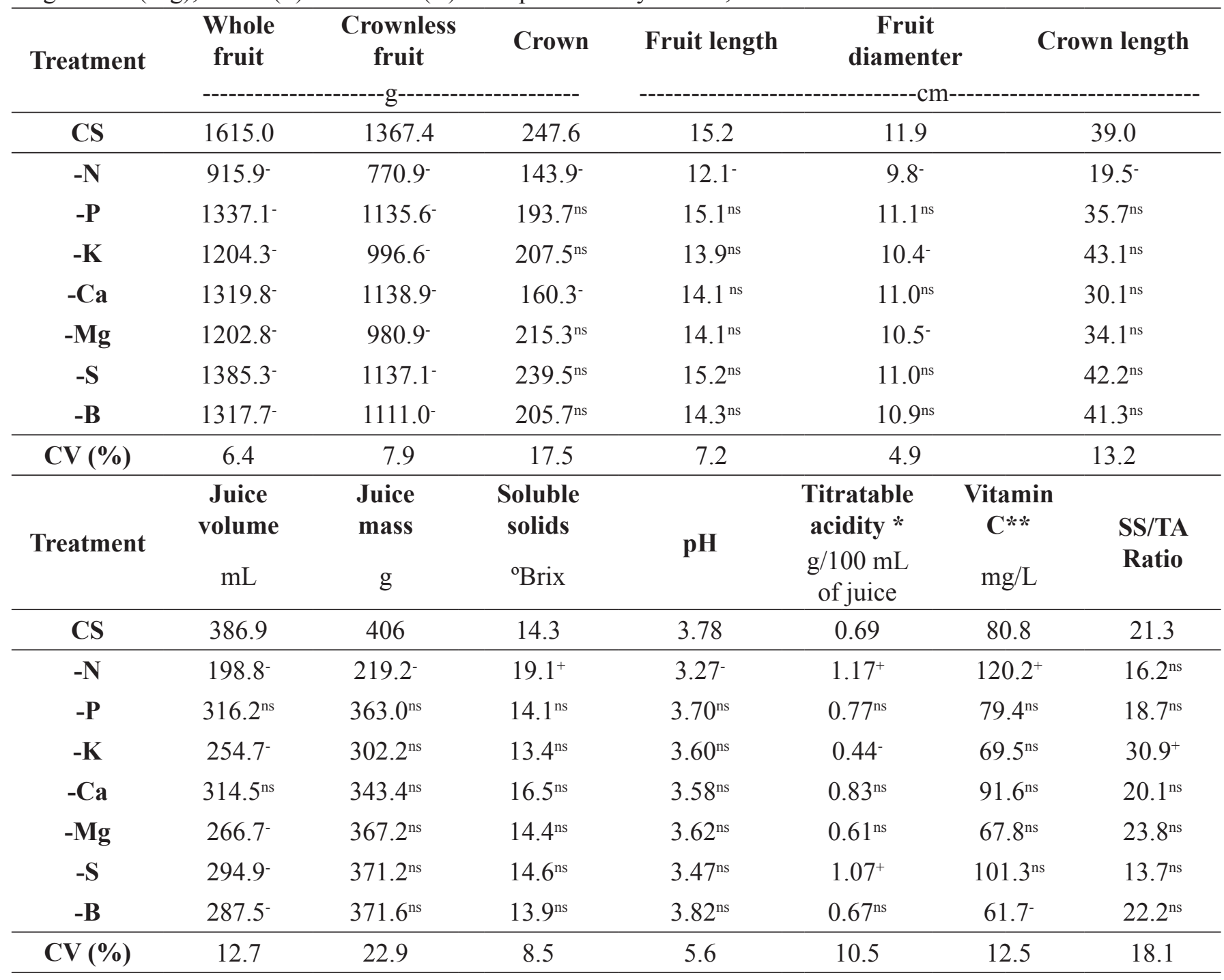

Values followed by "ns" were not significant; and by "-." were significantly lower than those observed in complete solution treatment; values followed by "+" were significantly higher than those observed in complete solution treatment compared by Dunnett's test at $5 \%$ significance.

* result expressed as a percentage of citric acid. ** result expressed in $\mathrm{mg}$ of ascorbic acid.

\section{Conclusions}

Isolated deficiencies of each macronutrient and boron reduced the fresh mass of the whole fruit and the crownless fruit.

The nutrient that most limited the size and quality of 'Vitoria' pineapple fruit was nitrogen.

Nutritional deficiencies of macronutrients and boron did not determine visual symptoms of deficiency in pineapple plants of 'Vitoria' cultivar in greenhouse conditions, with the exception of nitrogen deficiency, which resulted in yellowing of the plants' leaves.

\section{Acknowledgements}

The authors would like to thank the Carlos Chagas Filho Research Foundation of the state of Rio de Janeiro (FAPERJ) and the Coordination for the Improvement of Higher Education Personnel (CAPES) for financial support and scholarships. 


\section{References}

AMORIM, A. V; LACERDA, C. F. de; MOURA, C. F. $\mathrm{H}$; GOMES f, E. Fruit size and quality of pineapples $\mathrm{cv}$. Vitória in response to micronutrient doses and way of application and to soil covers. Revista Brasileira de Fruticultura, Jaboticabal, v.33, n.3, p.505-510, 2011.

AOAC- Association of Official Analytical Chemistry. Official methods of analysis of the Association of Official Analytical Chemistry. $20^{\text {th }}$ ed. Washington, 2016. 1115p.

AULAR, J., e NATALE, W. Nutrição mineral e qualidade do fruto de algumas frutíferas tropicais: goiabeira, mangueira, bananeira e mamoeiro. Revista Brasileira de Fruticultura, Jaboticabal, v.35, n. 4, p.1214-1231, 2013.

BARKER, D.L.; ARANTES, S.D.; SCHMIDT, E.R.; ARANTES, L.D.O.; SOARES, O.; FONTES, F.; BUFFON, S.B. Post-harvest quality of 'Vitória' pineapple as a function of the types of shoots and age of the plant for floral induction. Revista Brasileira de Fruticultura, Jaboticabal, v.40, n.4, 2018.

BENGOZI, J. F; SAMPAIO, A.C; SPOTO, M. H. F; MISCHAN, M. M; PALLAMIN, M. L. Qualidades físicas e químicas do abacaxi comercializado na CEAGESP São Paulo. Revista Brasileira de Fruticultura, Jaboticabal, v.29, n.3, p.540-545, 2007.

BERILLI, S. da S.; FREITAS, S. de J.; SANTOS, P.C.; OLIVEIRA, J. G.; CAETANO, L. C. S. Avaliação da qualidade de frutos de quatro genótipos de abacaxi para consume in natura. Revista Brasileira de Fruticultura, Jaboticabal, v.36, n.2, p.503-508, 2014.

BERILLI, S.S.; ALMEIDA, S.B.; CARVALHO, A.J.C.; FREITAS, S.J.; BERILLI, A.P.C.G.; SANTOS, P.C. Avaliação sensorial dos frutos de cultivares de abacaxi para consumo in natura. Revista Brasileira de Fruticultura, Jaboticabal, v.33, p.592-598, 2011. Volume Especial.

BHOWMICK, N.; GHOSH, S. K.; MUNSI, P.S.; DEB, P.; GHOSH, A. Effect of integrated nutrient management on flowering and fruiting characteristics of pineapple cv.Mauritius. Journal of Crop and Weed, West Bengal, v.13, n.2, 144-156, 2017.
BRASIL. Ministério da Agricultura Pecuária e Abastecimento. Instrução normativa $n^{\circ} 1$, de $1^{\circ}$ de fevereiro de 2002. Regulamentos técnicos de identidade e de qualidade para a classificação de abacaxi, uva fina de mesa e uva rústica. Brasília-DF, 2002. Disponível em: http://sistemasweb.agricultura.gov. br/ sislegis/actiondetalhaAto.do?method=visualizarAt oPortalMapa\&chave $=661183307$. Acesso em: 10 mar. 2019.

CAETANO, L.C.S.; VENTURA, J.A.; BALBINO, J.M.S. Comportamento de genótipos de abacaxizeiro resistentes à fusariose em comparação a cultivares comerciais suscetíveis. Revista Brasileira de Fruticultura, Jaboticabal, v.37, n.2, p.404- 409, 2015.

CAETANO, L.C.S.; VENTURA, J.A.; COSTA, A.F.S.; GUARÇONI, R.C. Efeito da adubação com nitrogênio, fósforo e potássio no desenvolvimento, na produção e na qualidade de frutos do abacaxi 'Vitória'. Revista Brasileira de Fruticultura, Jaboticabal, v.35, n.3, p.883890, 2013.

COELHO, R.I.; LOPES, J.C.; CARVALHO, A.J.C.; AMARAL, J.A.T.; MATTA, F.P. Estado nutricional e características de crescimento do abacaxizeiro 'Jupi' cultivado em Latossolo Amarelo distrófico em função da adubação com NPK. Ciências e Agrotecnologia, Lavras, v.31, n.6, p.1696-1701, 2007.

CQH - Centro de Qualidade de Horticultura; CEAGESP - Companhia de Entrepostos e Armazéns Gerais de São Paulo. Programa brasileiro para a modernização da horticultura: normas de classificação do abacaxi. São Paulo: Ceagesp, 2003. (Documentos, 24).

FAOSTAT. Food And Agriculture Organization Of The United Nations. 8 Statistic division. Disponível em: http:// faostat3.fao.org/faostatgateway/go/to/9browse/Q/QC/E. Acesso em: 30 jan. 2018.

FORNEY, C.F. Horticultural and other factors affecting aroma volatile composition of small fruit. HortTechnology, Kentville, v.11, n.4, p.529-538, 2001

GUARÇONI, A.; VENTURA, J.A. Adubação NPK e o desenvolvimento, produtividade e qualidade dos frutos do abacaxi 'Gold' (MD-2). Revista Brasileira de Ciência do Solo, Viçosa, MG, v.35, n.4, p.1367-1376, 2011.

HOAGLAND, D.R.; ARNON, D.I. The water-culture method for growing plants without soil. Berkeley: University of California, 1950. v.29, p.347. 
IBGE. Levantamento sistemático da produção agrícola 2016. Rio de Janeiro, 2017. Disponível em: www.ibge.gov. br/estatisticas/economicas/agricultura-e-pecuaria/9201levantamento -sistematico-da-producao-agricola.html. Acesso em: 11 abr. 2019.

KÜSTER, I.S; ALEXANDRE, R.S; ARANTES, S.D; SCHMILDT, E.R; ARANTES, L.O; KLEM, D.L.B. Phenotypic correlation between leaf characters and physical and chemical aspects of cv.Vitória pineapple fruit. Revista Brasileira de Fruticultura, Jaboticabal, v.40, n.2, p.e-964, 2018.

LEE, S. K.; ADEL A. K. Preharvest and postharvest factors influencing vitamin $\mathrm{C}$ content of horticultural crops. Postharvest Biology and Technology, Amsterdam, v.20, n.3, p.207-220, 2000.

MACHADO FILHO, G.C.; NASCIMENTO, I.R.; SAKAI, T.R.P.; ROCHA, W.S.; dos SANTOS, M.M. ${ }^{\circ}$ Brix analysis and green corn cob productivy by nitrogen fertilization time. Applied Research \& Agrotechnology, Guarapuava, v.11, n.1, p.33-41, 2018.

NEGREIROS, J.R. da S.; ARAÚJO NETO, S.E.; ÁlVAREZ, V.S.; LIMA, V.A.; OLIVEIRA, T.K. Caracterização de frutos de progênies de meios-irmãos de maracujazeiro-amarelo em rio branco - acre. Revista Brasileira de Fruticultura, Jaboticabal, v.30, n.2, p.431437, 2008.

OGAWA, E. M., COSTA, H. B., VENTURA, J. A., CAETANO, L., PINTO, F. E., OLIVEIRA, B. G., ROMÃO, W. Chemical profile of pineapple cv. vitória in different maturation stages using electrospray ionization mass spectrometry. Journal of the Science of Food and Agriculture, London, v.98, n.3, p.1105-1116, 2017.

OLIVEIRA, A.; GOMES, M.; PEREIRA, M.E.C.; NATALE, W.; NUNES, W.S.; LEDO, C.A.D.S. Quality of pineapple 'BRS Imperial' as a function of NK doses. Revista Brasileira de Fruticultura, Jaboticabal, v.37, n.2, p.497-506, 2015.

RAMOS, M.J.M.; MONNERAT, P.H.; PINHO, L.G.R.; CARVALHO, A.J.C. Qualidade sensorial dos frutos do abacaxizeiro 'imperial' cultivado em deficiência de macronutrientes e de boro. Revista Brasileira de Fruticultura, Jaboticabal, v.32, n.3, p.692-699, 2010.

RAMOS, M.J.M.; MONNERAT, P.H.da R.PINHO, L.G.; CARVALHO, A.J.C.; da SILVA, J.A. Morphological characteristics of' Imperial 'pineapple fruits under deficiency of macronutrients and boron. Acta Horticulturae, The Hague, v.822, p.147-154, 2009.
REINHARDT, D.H.R.; BARTHOLOMEW, D.P.; SOUZA, F.V.D.; CARVALHO, A.C.P.P.D.; PÁDUA, T.R.P.D.; JUNGHANS, D.T.; MATOS, A.P.D. Advances in pineapple plant propagation. Revista Brasileira de Fruticultura, Jaboticabal, v.40, n.6, 2018.

REINHARDT, D.H.R.C.; MEDINA, V.M. Crescimento e qualidade do fruto do abacaxi cvs. Pérola e Smooth Cayenne. Pesquisa Agropecuária Brasileira, Brasília, DF, v.27, n.3, p.435-447, 1992.

RIOS, C.; SANTOS, E.; NUNES, M.R.M.; de ALMEIDA, C.E.; COSTA, J.P. da; MELO SILVA, S. Quality of 'Imperial' pineapple infructescence in function of nitrogen and potassium fertilization. Revista Brasileira de Ciências Agrárias, Recife, v.13, n.1, p.1-8, 2018.

SALOMÃO, L.C.; PINHEIRO, R.V.; CONDÉ, A.R.; SOUZA, A.C.G. Efeitos do desbaste manual de frutos na produtividade e na qualidade dos frutos de pessegueiros (Prunus persica (L.) Batsch.), cultivar Talismã. Revista Ceres, Viçosa, MG, v.35, n.202, p.596-608, 1988.

SIEBENEICHLER, S.C.; MONNERAT, P.H.; CARVALHO, A.J.C. de; SILVA, J.A. da. Composição mineral da folha em abacaxizeiro: efeito da parte da folha analisada. Revista Brasileira de Fruticultura, Jaboticabal, v.24, n.1, p.194-198, 2002.

SILVA, A.L.P.; SILVA, A.P.; SOUZA, A.P.; SANTOS, D.; SILVA S.M.; SILVA, V.B. Resposta do abacaxizeiro 'Vitória' a doses de nitrogênio em solos de tabuleiros costeiros da Paraíba. Revista Brasileira de Ciência do Solo, Viçosa, MG, v.36, p.447-456, 2012.

SILVA, D.F.D.; PEGORARO, R.F.; MEDEIROS, A.C.; LOPES, P.A.P.; CARDOSO, M.M.; MAIA, V.M. Nitrogen and plant density in the economic evaluation and fruit quality of pineapple. Pesquisa Agropecuária Tropical, Goiânia, v.45 n.1, 2015.

SPIRONELlO, A., QUAGGIO, J.A., TEIXEIRA, L.A.J., FURLANI, P.R., SIGRIST, J.M.M. Pineapple yield and fruit quality effected by NPK fertilization in a tropical soil. Revista Brasileira de Fruticultura, Jaboticabal, v.26, n.1, p.155-159, 2004.

TAIZ, L.; ZEIGER, E.; MØLLER, I.M.; MURPHY, A. Fisiologia e desenvolvimento vegetal. 6.ed. São Paulo: Artmed Editora, 2017. p.858.

TEIXEIRA, L.A.J.; SPIRONELLO, A.; FURLANI, P.R.; SIGRIST, J.M.M. Parcelamento da adubação NPK em abacaxizeiro. Revista Brasileira de Fruticultura, Jaboticabal, v.24, n.1, p.219-224, 2002. 
VELOSO, C.A.C.; OEIRAS, A.H.L.; CARVALHO, E.J.M.; de SOUZA, F.R.S. Resposta do abacaxizeiro à adição de nitrogênio, potássio e calcário em Latossolo Amarelo do Nordeste Paraense. Revista Brasileira de Fruticultura, Jaboticabal, v.23, n.2, p.396-402, 2001.

VENTURA, J.A.; COSTA, H.; CABRAL, J.R.S.; MATOS, A.P. Vitória: new pineapple cultivar resistent to fusariosis. Acta Horticulturae, The Hague, v.822, p.51$56,2009$.
VIANA, E.S.; REIS, R.C.; JESUS, J.L.; JUNGHANS, D.T.; SOUZA, F.V.D. Caracterização físico-química de novos híbridos de abacaxi resistentes à fusariose. Ciência Rural, Santa Maria, v.43, n.7, p.1155-1161, 2013. 